\title{
THE ROLE OF LEGAL SERVICES IN THE ANTIPOVERTY PROGRAM
}

\section{A. KeNNETh PyE*}

It is a truism that law plays a vital role in social change. Likewise, there can be little doubt that lawyers individually and as a profession are frequently the architects of the law and are among the most significant contributors to the reformation of the social order. While it is clear that "lawyers maintain no monopoly on the arts of criticism, protest, scrutiny, and representation," it is equally certain that "lawyers are particularly well equipped to deal with the intricacies of social organization." The attorney's special aptitude may well result from what Riesman has called the "keen sense of relevance"2 which frequently distinguishes the lawyer's approach to social problems.

Lawyers, as a profession, have appreciated their obligation to utilize these talents for the common good. In 1958 the first Arden House Conference attempted to formulate a definition of the lawyer's professional responsibility. Representatives of the American Bar Association and the Association of American Law Schools undertook to redefine the role of the lawyer in American life, in a report which recognized not only the obligation of an attorney to provide fidelity and expertise to a client who could pay, but also "the lawyer's responsibility as a guardian of due process of law, his responsibility to make legal service available to all, his responsibility for representation of the unpopular cause, his responsibility for leadership in legal reform, and his responsibility to retain independence of thought and action as a citizen."

The newly declared "war on poverty" provides both an opportunity and an obligation for the profession to implement these statements of principle.

\section{The PAST}

Long before the war was declared, the profession and individual lawyers had taken important steps towards the realization of a legal system in which inequalities in economic status would not preclude the attainment of equal justice for the poor

* B.A. I95I, University of Buffalo; LL.B. 1953, LL.M. 1955, Georgetown University; Associate Dean and Professor of Law, Georgetown University Law Center; Chairman, Board of Directors, District of Columbia Neighborhood Legal Services Project. The views expressed are not necessarily those of the author's co-directors. The author expresses his appreciation to Peter D. Manahan, of the class of I966, Georgetown University Law Center, for his assistance in the preparation of this paper.

${ }^{1}$ Cahn \& Cahn, The War on Poverty: A Civilian Perspective, 73 YALE L.J. 1317,1334 (1964).

${ }^{2}$ David Riesman, Toward an Anthropological View of the Law and the Legal Profession, in INDIVIDUALISM RECONSIDERED 440 (I954).

${ }^{3}$ Countryman, The Scope of the Lawyer's Professional Responsibility, 26 Ono Sr. L.J. 66 (x965). The report may be found in 44 A.B.A.J. II59 (1958). 
as well as the rich. The profession had long recognized that the monopoly to practice the law entrusted to it by the people carried with it a correlative duty to provide "the services that only licensed lawyers can lawfully render to all those in need of such services." It had generally appreciated that it "must bear the responsibility for permitting the growth and continuance of two systems of law-one for the rich, one for the poor."

Before the turn of the century the legal aid movement began. The central idea was to supply legal advice and representation for the poor through a community law office manned by lawyers who were employed by the organization or by volunteers. ${ }^{6}$ By the end of the First World War 50,000 persons were served by legal aid, but less than $\$ 90,000$ was spent in providing the service. ${ }^{7}$ In the early twenties the organized bar, stirred by Reginald Heber Smith's classic, Justice and the Poor, began to take an active interest in the problem. The movement was benefited by prestigious leadership from men such as Charles Evans Hughes, William Howard Taft, and Elihu Root. However, their expectations were not easily realized and no substantial progress occurred until after the Second World War. Thus in 195I, Emery A. Brownell, at that time Executive Director of the National Legal Aid and Defender Association, concluded that until 1947 the proportion of the need being met over the country had remained virtually static and that "like the Red Queen of Alice in Wonderland, the Legal Aid forces have been obliged to run as fast as they could to stay where they were."

Beginning in the late forties, organized legal aid began to move at the national level. Distinguished leadership was provided by Harrison Tweed, Whitney North Seymour, Orison S. Marden, William T. Gossett, Howard C. Westwood, Theodore Voorhees, and others. Able administration was provided by Emery A. Brownell and Junius L. Allison and continued inspiration was supplied by Reginald Heber Smith. Funds became available as a result of the generosity of the bar, industry and labor, and the Ford Foundation. ${ }^{9}$

By April of 1965 there were 247 legal aid offices providing legal services to indigents in civil matters, an increase of over 300 per cent since 1949. ${ }^{10}$ Paid staffs

\footnotetext{
"Marden, Equal Access to Justice: The Challenge and the Opportunity, I9 WasH. \& LeE L. REv. 153, 154 (1962).

${ }^{8}$ Kennedy, Law Day, May I, I964, University of Chicago Law School Address by Robert F. Kennedy, quoted in Cahn \& Cahn, supra note $I$, at 1337 n.27.

- Marden, supra note 4, at 155 . The classic work outlining the history of legal aid in America is Emery A. Brownel, Legal Aid in the United States (195i).

${ }^{7}$ Marden, supra note 4 , at 158 .

${ }^{8}$ Brownell, Legal Atd in the United States 31 (I951), quoted in Carlin \& Howard, Legal Representation and Class Justice, 12 U.C.L.A.L. Rev. 381, 408 (1965).

- Marden, supra note 4, at I59.

${ }^{10}$ Statistics of Legal, Aid and Defender Work in the United States and Canada at 3 (i964) [hereinafter cited as Statistics of Legal AID]; Address by Howard C. Westwood, Annual Mecting of the National Legal Aid and Defender Association, Scottsdale, Ariz., Nov. 18, 1965 [hereinafter cited as Westwood Address].
} 
existed in 157 of these offices. ${ }^{11}$ Assistance was provided to indigents in 4I4,000 cases, an increase of almost fifty per cent since $1954^{12}$ The gross cost of operations of civil legal aid was four and a third million dollars. ${ }^{13}$ Legal services in over 206,000 criminal cases were provided by 162 defender organizations at a cost of approximately five million dollars. ${ }^{14}$ Thus, by the beginning of 1965 , exclusive of volunteer services, organized legal aid was providing representation in over $600,000 \mathrm{civil}$ and criminal cases at a cost of nine and a third million dollars. ${ }^{15}$

Nevertheless there were no legal aid facilities meeting the minimum standards of the National Legal Aid and Defender Association in I30 cities. ${ }^{16}$ In thirty-three offices the average caseload per full time attorney was 1678 new cases each year. ${ }^{17}$ Twelve other offices had average caseloads of rogo cases. ${ }^{18}$ Only twenty-five of seventy offices reporting had caseloads of less than rooo cases each year. ${ }^{19}$ The average salaries for professional personnel were well below the levels of government, business or private practice. ${ }^{20}$ Less than $2 /$ ro of one per cent of the total expenditures for legal services in the country went to finance the operation of all legal aid organizations in the United States handling civil cases. ${ }^{21}$ Some authorities estimated that only about ten per cent of the persons needing legal aid were being served by existing legal aid organizations. ${ }^{22}$

The extent to which the legal needs of the poor were being met by organized legal aid and the capacity of the legal aid movement to expand to meet these needs had posed troublesome questions to thoughtful observers for some time. The importance of seeking answers to these questions became paramount with the passage of the Economic Opportunity Act of $1964 \cdot{ }^{23}$ Title two of the act authorized the grant of federal funds to cover ninety per cent of the costs for approved community action programs. ${ }^{24}$ Shortly after its inception the Office of Economic Opportunity (OEO) determined that projects designed to provide legal services were

\footnotetext{
${ }^{11}$ Statistics of Legal and 2.

${ }^{12}$ Id. at 3; Westwood Address.

${ }^{10} \mathrm{Ibid}$.

${ }^{14}$ Ibid.

15 Ibid.

${ }^{10}$ National Legal Am and Defender Ass's, President's Annual Report for ig65 [hereinafter cited as President's Ann. Rep.].

17 Natjonal Legal Aid and Defender Ass'n, Sumgmary of Data on Legal Aid Offices in ComMUNITIES OF IO0,000 AND OVER FOR THE YEAR OF 1964 , at I (1965).

${ }^{18} \mathrm{Ibid}$.

${ }^{10}$ Ibid.

${ }^{20} I d$. at $2-3$. The average salaries for professional personnel range from $\$ 3900$ (attorneys) and $\$ 7332$ (executive attorneys) in cities between 100,000 and 250,000 to $\$ 7504$ (attorneys) and $\$ 1 \mathrm{I}, \mathrm{I} 62$ (executive attorneys) in cities of over 750,000 . Only 33 of 87 reporting offices provided retirement benefits and less than one-third provided hospital or medical benefits such as Blue Cross or Blue Shield.

${ }^{21}$ Carlin \& Howard, supra note 8, at 4 Io (estimated for year 1963).

22 Ibid. (estimated for year 1964 ).

${ }^{20} 78$ Stat. 508, 42 U.S.C. $\$ \$ 270 I-981$ ( 1964$)$.

as Ibid.
} 
among the types of community programs for which federal funding was available under the act. ${ }^{25}$

In February of 1965 the House of Delegates of the American Bar Association pledged itself "to cooperate with the Office of Economic Opportunity and other appropriate groups in the development and implementation of programs for expanding availability of legal services to indigents and persons of low income, such programs to utilize to the maximum extent deemed feasible the expertise and facilities of the organized bar, such as legal aid, legal defender and lawyer referral and such legal services to be performed by lawyers in accordance with ethical standards of the legal profession."26

A sound national program necessarily required decisions as to how many people needed legal services, what kinds of programs should be subsidized by federal funds, what were the best ways to provide these services, how much would they cost, to what extent grants of federal funds would be accompanied by the assertion of federal control over local community policy making, to what extent federal policies would require lay participation in deciding matters traditionally determined by the profession and similar matters. Of even greater importance was the determination of the principal objectives of the national program and the establishment of priorities among them. Matters of general concern became matters of urgency. As OEO enters its second year, we still do not know enough about these essential questions.

\section{ThE ExTENT OF THE NEED}

How many people are in need of legal services and are unable to afford them? The number of variables precludes the development of an equation which can be used as a unit of accurate measurement. It is obvious that we must have some notion of what kind of legal services poor people need and some concept of when a person is to be regarded as poor. The relationship between the kind of legal service sought, the income of the person seeking the service, and his other financial responsibilities may constitute a reasonable test for whether services should be provided to a given individual without charge. But such a standard makes it

\footnotetext{
${ }^{25}$ The 1965 amendments make it clear that legal service programs may be funded. Economic Opportunity Amendments of 1965, 112,79 Stat. 973: "The last sentence of section 205(a) of the Economic Opportunity Act of 1964,42 U.S.C.A. $\$ 2785$ (a) is amended by inserting after 'including' the following: ", but not limited to,:" The Senate Report clarifies the reason for the change: "The listing of activitics in section $205(\mathrm{a})$, of course is not intended to exclude other types of activities related to the purpose of community action programs, such as legal services for the poor, family counseling, or community organization activities. In order to make this absolutely clear, the committce has also included an amendment to this section which would indicate that programs are to be conducted in fields, including 'but not limited to' those which are specifically enumerated." I4 U.S. CODE CoNG. \& AD. NEws 4835 (1965).

${ }^{26}$ Quoted in Patricia Wald, Law and Poverty: 1965, Report to the National, Conference on LAw and Poverty 68 (I965) [hereinafter cited LAW aNd Poverty]. Sec McCalpin, The Bar Faces Forward, 51 A.B.A.J. 548 (1965).
} 
difficult to estimate how many others experience a like need, or even the capacity of this individual to afford other legal services of a different nature.

Perhaps the problem can be seen most clearly in the administration of criminal justice. Even in this narrow field there are clear distinctions in the nature and costs of different types of legal services, and inherent limitations upon the manner in which they may be provided, arising out of factors such as the volumes of cases involved, the times at which the services must be made available if they are to be significant, and the degrees and types of expertise required for adequate representation. There can be little doubt that legal services are necessary, and indeed required by the Constitution in felony cases, ${ }^{27}$ when a defendant is brought before the court for arraignment or trial. However, legal services are also needed by the defendant who wishes to appeal, to attack his conviction collaterally, to obtain his release from a mental hospital to which he has been committed, to seek parole, and in probation revocation proceedings. ${ }^{28}$ Likewise before trial the defendant has need of legal services at a preliminary hearing and may need the assistance of a lawyer in negotiations with the prosecutor before the decision of whether to charge has been made. He may also need a lawyer's advice during a police interrogation. ${ }^{29}$ To these examples must be added the cases in which legal advice is needed by persons contemplating conduct the legality of which is unclear, witnesses whose cooperation is sought by the police or defendants, and similar counseling.

The volume of cases involved varies significantly with the stage of the proceeding at which the assistance is needed. It has been estimated that there are approximately 300,000 felony cases and 4,500,000 misdemeanor cases in the state courts each year. ${ }^{30}$ To this must be added 33,000 cases in the federal courts. ${ }^{31}$ In Ig64 there were thirty-five arrests for all criminal acts for each $I, 000$ persons in the country. ${ }^{32}$

At least half of the defendants charged with felonies cannot afford a lawyer. ${ }^{33}$ Presumably a higher percentage could afford an attorney in the less serious misdemeanor case. A small percentage of defendants charged with crime can afford counsel for an appeal, and fewer still will have funds when a hearing is scheduled before a parole board after years of imprisonment. The costs of services of a lawyer at a preliminary hearing or at a station house interrogation may be within the means of more people, but few private practitioners are available at the times when

\footnotetext{
${ }^{27}$ Gideon v. Wainwright, 372 U.S. 335 (I963); cf. Harvey v. Mississippi, 346 F.2d 263 (5th Cir. 1965).

${ }_{38}$ LAW AND POVERTY 35-39.

${ }^{30}$ See Silverstein, The Continuing Impact of Gideon $v$. Wainturight on the States, 5I A.B.A.J. 1023 (Ig65).

${ }^{30}$ Lee Silvertein, Defense of the Poor in Criminal Cases in american State Courts: A PreLIMINARY SURVEY $35,36(1964)$.

${ }^{31}$ Report of the Atr'y General's Comm. on Poverty and the Administration of Federal CrimINAL JUSTICE I6 ( 1963$)$.

${ }^{32}$ Uniforal Crime Reports for the United States-1964, at 24 (1965).

${ }^{33}$ Silversteln, op. cit. supra note 30 , at $\mathrm{I}$.
} 
these services are needed. The expertise required of the lawyer to try the criminal case is of a different nature than the skills involved in briefing and arguing an appeal or in advising a client whether to cooperate at a police interrogation.

Collateral factors such as the possibility of release on personal recognizance with no necessity of paying a bond premium, whether pretrial release can be obtained soon enough to avoid loss of employment, and the flexibility of court rules permitting alternatives to expensive printed briefs, affect the capacity of the defendant to pay the fee required by the private practitioner.

Perhaps most important are fundamental notions of when free services should be provided. Should we require a defendant to spend the small amount of cash in his possession for an attorney when the funds would otherwise have been used for food, housing and clothing for those who look to him for their support? Should we provide free legal services to a defendant who has an equity in a car, owns a television set, is able to post bond, and has intermittent employment? Such a person may be unable to pay the fee required by established members of the profession but can pay an amount acceptable to the "moonlighter," the occupier of the "mourner's bench," or the newly admitted practitioner who is prepared to take any case for "experience."

Local factors such as the unemployment rate, wage scales, the number of lawyers available, the structure of the bar, its experience with legal aid, the academic, economic, and social backgrounds of its members and its attitudes towards social responsibility also play a significant role.

The variables are even more complex in the civil arena. Here the need for counseling and representation in negotiations, in administrative proceedings, and in court, run the gamut of landlord tenant problems, consumer credit, the administration of public welfare laws, domestic relations cases, proceedings involving juveniles, and countless other problems.

Many of the same legal problems which face the middle class citizen confront the poor man. In addition he may need help in areas in which the more affluent are not involved such as the determination of eligibility of public assistance or the assertion of the right to a partial refund for the payments made on furniture purchased on credit. ${ }^{34}$ The poor man because of his lack of education and social status, may need representation in matters such as a dispute with a high school principal over the dismissal of a child, ${ }^{35}$ or the assertion of a complaint for a violation of the health or building code by a landlor $\mathrm{d}^{36}$ under circumstances where the

\footnotetext{
${ }^{84}$ The range of legal problems facing the poor is outlined in LAW AND PoverTy 6-35; HEW, Conference Proceedings, The Extension of Legal Services to the Poor i7-70 (1964) [hercinafter cited as HEW Conference Proceedings].

${ }^{85}$ In May of 1966 the Neighborhood Legal Services Project (NLSP) in Washington, D.C., obtained the reinstatement of a married senior high school student who was expelled from school three weeks before graduation solely on the ground that she had become pregnant.

${ }^{86}$ In another case, NLSP provided representation to a client who claimed that her cviction resulted
} 
better educated citizen could speak for himself. Former Attorney General Robert F. Kennedy has pointed out that lawyers are needed to "make law less complex and more workable," "to assert rights which the poor have always had in theory but which they have never been able to assert on their own behalf"; to practice "preventive law" by counseling "about leases, purchases, a variety of common arrangements whereby he [the poor man] can be victimized and exploited," and "to begin to develop new kinds of legal rights in situations that are not now perceived as involving legal issues."37

It is not surprising that estimates of the numbers of persons who need services of these diverse kinds vary widely. Some authorities have indicated a national average of at least seven ${ }^{38}$ to $\operatorname{ten}^{39}$ per thousand of the population as a measure of those needing legal aid services. This would mean a total of $1,400,000$ to 2,000,000 persons. In 1958 the Legal Aid Commission of the Bar Association of the District of Columbia estimated the number at eighteen per thousand for the District. ${ }^{40}$ Another authority has estimated that one-third of the thirty-five million poor have legal problems. ${ }^{41}$ In December, the Director of the Office of Legal Services of the Office of Economic Opportunity stated that the object of its program was to "better the lot of over thirty million people in our nation by providing competent lawyers for them." ${ }^{\text {2 }}$ In January the Office of Economic Opportunity referred to the necessity of providing lawyers for the nation's poor-"some 35,000,000 persons in families with annual incomes under $\$ 3,000 . " 43$ This estimate, which seems to have intended to include all of the poor, is probably the most accurate. It is difficult to see how any poor person can attain maturity and at no time have need for legal advice. The fact that many do not know that they have legal problems, or do not seek the assistance of a lawyer to advise them when problems are perceived, does not mean that they have no need for legal assistance. The percentage seeking the advice of a lawyer is only a fraction of those who could and should benefit from such advice. Furthermore, the demand for legal services increases directly in proportion to their availability and the publicity accorded to them. Only after legal services are provided and the poor are informed of their availability and importance will the true dimensions of the problem be known.

Even if it is assumed that all of the poor will need legal services at some time,

solely because she gave information of unsafe and uninhabitable conditions of her apartment to the Department of Licenses and Inspections in the District of Columbia. Litigation in the matter is pending.

${ }^{37}$ Kennedy Address, supra note 5, at 1337 n.27.

${ }^{88}$ Marden, supra note 4 , at 54 , relying upon Brownell, op. cit. supra note 6 , at 79.

${ }^{30}$ Carlin \& Howard, supra note 8, at 409, paraphrasing Brownell, op. cit. suspra note 6, at ro8.

${ }^{40}$ Report of the Comm'n on Legal Aid of the Bar Ass'N of the District of Columbia i38-40 (r958).

${ }^{2}$ Law and Poverty 47 , relying on Brownell, op. cit. supra note 6, at 57.

12 Address by E. Clinton Bamberger, before the Bar Association of Baltimore City, December I5, 1965 [hereinafter cited as Bamberger Baltimore Address].

\& Office of Economic Opportunity, Guidelines for Legal Services Program (preliminary copy, 1966) [hereinafter cited as JANUARY Guidezines]. 
the determination of the Plimsoll line of poverty remains. When is a man "poor" in the sense that he should be provided legal services in civil matters without charge? Little light has been cast upon the issue of the standard for eligibility. There has been a broader understanding that the standard must vary in different localities. Attempts to formulate a national standard would be more misleading than helpful. ${ }^{44}$ Furthermore, there has been a growing appreciation that what may be poverty for the purpose of entitling an applicant to public welfare assistance may be a totally inadequate standard for determining eligibility for legal services. The problem is complicated by the fact that not only the poor are being deprived of legal services because of an inability to afford them; a substantial portion of our middle class finds that the profession's traditional methods of making legal services available result in a price beyond their capacity to pay. ${ }^{45}$ Even if we are able to succeed in "elevating" all of the poor to the middle class, a "services gap" will continue unless the profession alters some of its approaches towards the permissible methods of making legal services available. ${ }^{46}$

Even the most sanguine do not prophesy the end of poverty in the near future.' The national assault on poverty and the anticipated increase in national prosperity may reduce the percentage of our population which is classified as "poor," but the absolute numbers will still probably increase. In I950 our population was just over

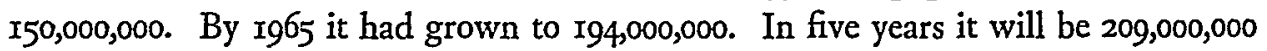
and in fifteen years, $245,000,000 .^{4 \pi}$

Furthermore, the availability of legal services to individuals is determined in part by the competitive factors of supply and demand. Increases in the size of the profession have thus far kept pace with population growth. ${ }^{48}$ However, the expansion in the demand for lawyers by industry and government is increasing at an even greater rate than the demand by private individuals. ${ }^{48}$

\footnotetext{
"4 "The standard should realistically separate those who can afford to pay for legal services from those who cannot. Such a standard may take into consideration the size of the family, the health of its members, recent unemployment, debts and the like. Discretion may be given in order to avoid inflexible rules which cannot cover every particular situation . . . " Tentative Guidelines for Legal Service Proposals to the Office of Economic Opportunity, Appendix A, in LAW AND PoverTy, op. cit, supra note 26, at II2, II4-15, [hereinafter cited as SPRING GuIDELINEs].

${ }^{45}$ Cheatham, A Lawyer When Needed: Legal Services for the Middle Classes, 63 Colua. L. REv. 973 (1963).

"Ibid. See also Cheatham, Availability of Legal Services: The Responsibility of the Individual Lawyer and of the Organized Bar, I2 U.C.L.A.L. REv. 438 (1965). In this article I attempt to deal only with the problem of providing legal services to the poor-whoever they may be determined to be. For that reason, I have generally ignored the significant contribution of lawyer referral systems, which, while in theory providing an attorney for those who can pay a modest fee, in fact, have been providing legal services to many who could not afford to pay the fee normally charged for the services rendered. The larger problem of making legal services generally available is now under study by the A.B.A. Special Committee on Availability of Legal Services.

${ }^{47}$ Westwood Address. Mr. Westwood's statistics were obtained from U.S. DEP'T of Conmarce, Bureau of the Census, Current Population Reports yo (Series p-25, No. 304, 1965).

${ }^{18}$ Faye A. Hankin \& Duane W. Krohnke, The American Lawyer: ig64 Statistical Report 26 (1965).

${ }^{10}$ Id. at 22.
} 


\section{The Problems for OEO}

The extent of the need for legal services by the poor is only one of the problems. A finding that the need is far beyond the capacity of existing legal aid organizations does not necessarily require the conclusion that OEO should become involved in financing local programs which are primarily designed to provide more legal services to more needy persons. Its professed commitment to the development of programs designed to attack poverty, rather than to programs designed only to provide services to those who are poor, might result in the conclusion that legal services to poor persons with individual problems should be financed primarily from state or local sources; but that federal funds should be used primarily to fund programs which seek to provide legal components to non-service oriented projects designed to evaluate the causes of poverty, develop devices for increasing mobility into the middle class, and devising new institutions and changing existing institutions to increase the power and improve the status of those who remain in poverty.

Even if it is decided that a principal purpose of OEO's legal service program is to increase and broaden the legal services available to the poor in local communities, it is necessary to determine whether this objective can best be met by OEO funding of expanded programs of existing legal aid organizations, new types of organizations, such as neighborhood law offices, programs designed to subsidize individual members of the bar, programs for providing legal services to groups of the poor who have similar legal problems, or by other alternatives.

Flexibility is clearly desirable. New methods should be the subject of experimentation. Combinations of methods should be utilized in some areas. A premium should be placed on novelty and creativity. But agreement on such platitudes can not obscure the necessity of determining the basic objectives of OEO-financed legal service programs. To a large extent the choice of the programs to be financed must depend on the major objectives sought to be achieved.

\section{The First Year at the National Level: OEO}

The experience of the first year may provide an indication of the directions in which we are proceeding. Initially, organized legal aid seemed to take the position that existing organizations, supplemented by new legal aid societies organized after the traditional model in cities where none now exists, could meet the need if provided with the funds necessary to achieve this purpose. Specifically, the Executive Committee of the National Legal Aid and Defender Association adopted a statement in December of $\mathrm{r} 964$ which advanced the propositions:

L. With ample funds, traditional legal aid and defender organizations can be broadened to meet the full legal needs of indigent people in metropolitan centers.

M. The creation of separate, duplicating agencies to offer legal services under 
Economic Opportunity programs will be more costly and less effective than will proper use of existing facilities, and serious ethical questions will be raised where nonlawyers attempt to practice law. ${ }^{50}$

Most informed observers agreed that existing legal aid organizations could come closer to meeting their objectives with additional funding, but several knowledgeable observers questioned whether the federal funds could be used best by providing financial support to them. Even if primary emphasis was to be placed on providing services, there was concern that legal aid should not have the monopoly. In November of Ig64, Attorney General Katzenbach made the point:

There has been long and devoted service to the legal problems of the poor by legal aid societies and public defenders in many cities. But without disrespect to this important work, we cannot translate our new concern into successful action simply by providing more of the same. There must be new techniques, new services, and new forms of inter-professional cooperation to match our new interest. ${ }^{51}$

Professor Marvin E. Frankel suggested that there were deficiencies within existing legal aid organizations which prevented them from accomplishing the objectives by themselves. He argued that the mere fact that they were old and established raised the specter of the "negative impact of habit, of routine" and "settled bureaucratization"; that there was a tradition of welfare colonialism in legal aid in which the business community and the bar provided services to a passive poor without any attempt to enlist their participation in a program for their own betterment; that the traditional structure of legal aid followed the model of providing a centralized legal office frequently inaccessible to many of the poor; and that existing legal aid organizations had failed to educate the poor concerning the circumstances in which they needed legal advice or the availability of counsel to assist them. ${ }^{62}$ In his opinion legal aid should not be excluded, but new experimental possibilities should be explored.

His Columbia colleague, Monrad G. Paulsen, reached similar conclusions and argued that the participation of existing legal aid organizations should be limited to "the strongest and most adventurous societies." were not established the full extent of the opportunity to benefit the poor by legal services might not be realized:

In part, legal services for the poor must aim at constructive social changes. Part of the law work must be undertaken to attack established institutions, practices and rules, in order that social progress may be made. The focus of much of the work will be general reform rather than the special aim of assisting a given

\footnotetext{
${ }^{50}$ Quoted in Frankel, Experiments in Serving the Indigent, 5I A.B.A.J. 460 (1965). The text may be found in 5 I A.B.A.J. 275 (1965).

61 HEW Conference Proceedings iI.

${ }^{62}$ Frankel, supra note 50, at 460-62.

${ }^{63}$ Paulsen, The Expanding Horizons of Legal Services, 67 W. VA. L. Rev. 179, I90 (1965).
} 
person with his particular legal difficulty. Few legal aid societies are geared to such work.

If the right kind of legal assistance is to be provided, it will often take the form of a new agency, the character of which we ought to see clearly in advance and which we ought to set up in full recognition of its controversial character. . . 54

Messrs. Carlin and Howard were even less charitable. They considered that existing legal aid was derelict in excluding many who were unable to pay a fee. Such policies, in their opinion, resulted in no legal services being provided to many applicants, the penalizing of the thrifty, the alienation of the poor, and the de-personalizing of the lawyer-client relationship. ${ }^{55}$ They found fault with policies of many legal aid organizations in refusing to take divorce and bankruptcy cases ${ }^{56}$ and criticized the standard case loads approved by the National Legal Aid and Defender Association as being grossly excessive. ${ }^{57}$

Spokesmen for organized legal aid were quick to admit that many of the objections had merit but pointed out that the criticisms were not new. The National Legal Aid and Defender Association had called attention repeatedly to the fact that rules governing types of cases handled were too limited; the general eligibility policies of some organizations were too restrictive; that more of the services should be decentralized; that governing bodies were not sufficiently representative of the communities served; and that staff salaries were shockingly low. In the opinion of organized legal aid, however, in most communities there were few deficiencies which could not be cured by an adequate budget. ${ }^{58}$ On this premise the National Legal Aid and Defender Association on behalf of its members sought the assistance and funding of the Office of Economic Opportunity.

The decision to seek federal funds was not unanimous. Spokesmen for some legal aid organizations preferred to continue as private charitable organizations without federal funding. ${ }^{59}$

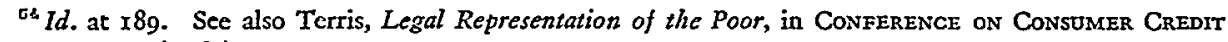
AND THE POOR (I965).

${ }^{\text {s5 }}$ Carlin \& Howard, supra note 8, at 4II-I2.

${ }^{50} I d$. at 413-I6. But in 196459 legal aid societies handled 6296 divorce cases, secured decrees for 3652 clients, and defended I court cases for these offices. NLDA Divorce Statistics: 1964 ( 1965 ). Other societies declined to represent plaintiffs or applied a standard of "social desirability."

or Carlin \& Howard, supra note 8, at 4I6. When Carlin and Howard wrote, the standard was that set in 1960 of one full time attorney for the first 750-1000 cases per year and an additional full time attorney for each additional I200 cases (or equivalent part time attorneys) for cities of more than 100,000 population. In 1965 NLDA amended its standards to provide that in urban communities of at least 75,000 population per 100 square miles of land area, there should be at least one full time lawyer if the society's caseload is 400 or more matters per year. The caseload of a full time lawyer should not exceed 900 matters each year. NLDA Standards and Practices for Crvil Legal Aid (1965). It should be remembered that reference is made to minimum standards. Furthermore, there is no clear definition of a "case" or a "matter." Usually any direct contact between a legal aid staff attorney and a client is considered to be a "case" or "matter" for reporting purposes.

to President's ANN. Rep. 5.

${ }^{50}$ Schein, Legal Aid Utopia, 33 D.C.B.J. 16 (1966); Fisher, The Role of the Legal Aid Society, 32 D.C.B.J. 375 (Ig65); see Bradway, Two's Cospany, 1966 Duke L.J. No. 2. 
In November of 1964 the Department of Health, Education and Welfare conducted a Conference on the Extension of Legal Services to the Poor. The Conference coordinator, John G. Murphy, Jr., assembled spokesmen with diverse viewpoints from throughout the country to discuss the legal needs of the poor, new models for legal service programs, the relationship between lawyers and social workers, and the role of law schools in the forthcoming war. ${ }^{60}$

Some observers viewed the problem as a choice between two distinct approaches. The first approach would place principal emphasis upon existing legal aid organizations with close relationships with the organized bar; legal aid societies managed by old time legal aiders with higher salaries and with larger staffs, under policies negotiated between OEO and the organized bar and with the major objective of providing more and better representation for individuals who could not afford a lawyer.

A second approach would place the emphasis on federal funding of new organizations staffed by lawyers unconnected previously with the legal aid movement; organizations which sought to effect social change for the poor through a more sophisticated use of the legal process than the representation of masses of individuals with personal legal problems; programs which were prepared to decline legal assistance to eligible applicants if providing representation to such persons would overburden their staffs with caseloads which would hinder them in achieving their major objective of social, economic and legal reform through the litigation of test cases, the drafting of ordinances, rules and statutes and lobbying for their passage, and the participation with other professionals or subprofessionals in the organization of neighborhood groups which would bring economic and political pressure to bear on business, the police, the courts, school boards, administrative agencies, mayors and city councils to obtain redress for real or imagined grievances and the assurance of equal or preferred treatment in the future; projects which would welcome bar support, but which were willing to regard the bar as an adversary if ageement could not be reached on issues such as indigency standards, involvement with groups engaging in civil disobedience, programs advertising the availability of legal services and encouraging the assertion of legal rights, or the representation of groups and members thereof. Others argued that the approaches were not inconsistent. A compromise should be reached.

This was the setting in which the Office of Economic Opportunity began to determine the policies which it would follow. Fortunately, there were capable people available to make the decisions.

Edgar S. Cahn, a brilliant and incisive innovator, left the Department of Justice to join OEO. In July of 1964 , the month before the act was passed, Cahn and his wife, Jean, had published the landmark article, The War on Poverty: $A$ Civilian Perspective, ${ }^{61}$ in which they had advocated as "one kind of institution" the establish-

\footnotetext{
${ }^{\circ}$ HeW CONFerence Proceedings.

${ }^{61} 73$ YALE L.J. I3I7 (1964).
} 
ment of a university-affiliated neighborhood law firm which "would represent persons and interests in the community with an eye towards making public officials, private service agencies, and local business interests more responsive to the needs and grievances of the neighborhood."62 For a few winter months Jean C. Cahn also served in the Office with the responsibility of developing a legal services program within the Community Action Program (CAP). Differences of opinion with reference to the status, importance and independence of the legal services program developed and Mrs. Cahn resigned. During the spring of 1965 the organizational status of the legal services program of OEO was unclear. Within the Community Action Program, B. Michael Rauh served as a special assistant for legal services. In the Office of General Counsel, Bruce J. Terris and John G. Murphy, Jr., were also involved in the development of the policies relating to the program. The lines of authority between the Office of the General Counsel and the Director of Community Action Program were not always clear.

A document, Tentative Guidelines for Legal Services Proposals to the Office of Economic Opportunity, ${ }^{63}$ was prepared in the early spring. It adopted a flexible attitude towards the question of whether existing legal aid organizations should be subsidized:

... Whether the legal services program is run by legal aid, a bar association, an independent organization or by a combination of organizations is a matter for local determination. The only question for OEO is whether the organization, however established, can provide the best possible legal services for the poor.

The proposal may extend and improve already existing services, such as legal aid, add new legal services through a new institution to those already existing, or provide a full range of services, as where no legal services are provided in the neighborhood. In any event, the new programs should avoid duplication and be conducted in cooperation with other legal programs for the poor in the locality. ${ }^{64}$

The Guidelines required that programs be a part of a coordinated community action program wherever possible, ${ }^{65}$ but that it nevertheless be organized in such a manner that it was independent of the organizations, including the local community action program, with which it might have a conflict of interest. ${ }^{66}$ The memorandum provided that any proposals submitted for funding should attempt to deal with the full scope of legal problems of the poor and at each stage, from advice and counseling through appeal. ${ }^{67}$ In addition, emphasis was placed upon providing representation for organizations of the poor. ${ }^{68}$ Applicant organizations were cautioned that any pro-

\footnotetext{
${ }^{02}$ Id. at 1334. For a discussion of the development of the neighborhood law offces, see infra, pp. $23 \mathrm{I}-43$.

${ }^{83}$ Spring Guidelines.

of Id. at II3, II5.

${ }^{\text {ot }}$ Id. at II3.

${ }^{\circ 0} \mathrm{Id}$. at II 4 .

${ }^{87}$ Id. at II5.

${ }^{\text {es }}$ Id. at II6.
} 
posal should give consideration to the role of the legal services program in defining or changing the law where it was unclear or detrimental to the interests of the poor, ${ }^{69}$ and that it should contain provisions for the education of the poor. ${ }^{70}$ Applicants for funding were warned against "artificial limitations which would prevent comprehensive services," and any limitations or priorities were required to be justified. ${ }^{71}$ It was made clear that offices should be decentralized ${ }^{72}$ and that proposals should set forth the method of referral of persons who did not meet the standards of eligibility. ${ }^{73}$ Notice was given that it was the policy of the act that legal services be "developed, conducted, and administered with the maximum feasible participation of residents of the areas and members of the groups served."74 Specifically, the Guidelines provided: "This participation should be ensured, whenever possible, by having the residents represented on the board of directors and advisory committees to the project. ..."75

Most legal aid organizations were required to change their structure, decentralize their offices, and expand the scope of their services in order to adhere to the Guidelines and qualify for federal funds.

Throughout the spring, efforts were made by leaders of the bar and of legal aid (often the same persons) to narrow what originally had seemed to be a substantial breach between $O E O$ and organized legal aid. An important element in the equation was a growing realization by OEO of the importance of continued support from the leaders of the bar. The endorsement of the American Bar Association, obtained in February, needed to be reiterated as charges of the "socialization of the bar" began to be heard. ${ }^{78}$

The chief vehicle of the bar for providing legal services to the poor traditionally had been legal aid. Lack of confidence in legal aid often involved implicit criticism of the profession's past contributions. Those concerned with legal service programs in OEO had well-grounded fears that the bar might oppose the use of federal funds even by existing legal aid organizations if conditioned upon such a broad scope of activities and the necessity of the participation of the poor in policy decisions which would include indigency standards and other matters regarded traditionally as within the prerogatives of the profession. To set up a new organization in competition with an existing legal aid society posed serious problems of lack of bar support in many communities. On the other hand, some of the more militant reformers thought that bar control of legal service programs would preclude any aggressive program aimed at institutional changes.

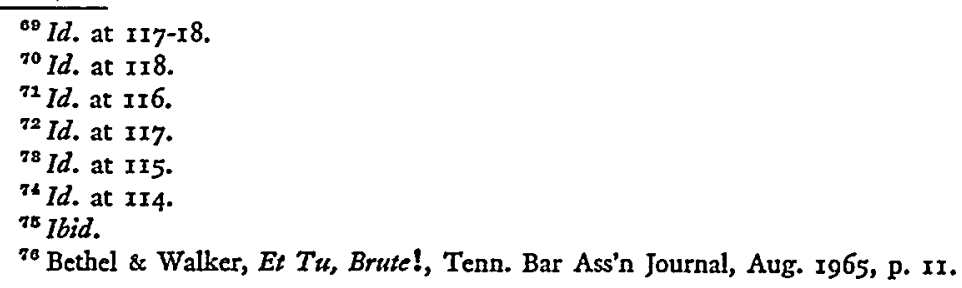


Continued efforts to bring OEO, the bar and legal aid together were made by the American Bar Association, led by its President Lewis F. Powell, Jr., and with almost daily contact by Lowell $R$. Beck of its Washington staff. OEO obtained independent advice from consultants, most of whom were law professors who had participated in the November $1964 \mathrm{HEW}$ Conference, and from a steering committee selected to plan a National Conference on Law and Poverty, to which leaders of the bar would be invited.

In June, Theodore M. Berry, Director of the Community Action Program, addressed the Conference on the subject of OEO policies:

I would now like to answer as explicitly and directly as I can the question which has been asked repeatedly by leaders of the bar. What is the role of Legal Aid Societies in OEO's plans? My response is simply that this determination is not OEO's at all; instead, the local community must decide what organization or organizations can best handle legal services for the poor. Indeed, in many places several different groups may well provide services in different kinds of cases or in different geographic areas. Such programs may be run by a Legal Aid Society, a foundation, a university, or by a new nonprofit corporation. The sole standard-which I have stated before-is what group or groups is most dedicated and most competent to provide legal services for the poor and will receive the confidence and use of the poor.

While the determinations will be made in local communities, we in OEO hope and expect that many proposals will come from Legal Aid Societies. Many of these societies are strong organizations which can take on new vitality with additional funds. On the other hand, we also hope that other groups will make proposals to try out different ideas and methods. The resulting competition of ideas and services should benefit everyone.

I think the grants which OEO has already made and the proposals which have come to it indicate the pattern. They demonstrate that Legal Aid Societies far from being excluded will either themselves receive substantial funds or will at least participate with other organizations which will receive funds.7

At the same time, however, the policy on "poor on the board" hardened. No longer were the "residents" to be "represented whenever possible." Now it was to be required, and the percentage of representation set forth:

... Normally, this means that approximately one-third of the governing board of the legal service program should be, in the words of the statute, "residents of the areas and members of the groups served." This is a suggested yardstick. Advisory committees of neighborhood residents should be established around each neighborhood office. But this alone is not sufficient. These committees should be permitted to choose representatives on the board of directors of the entire program.... ${ }^{78}$

77 Address by Theodore M. Berry, Director, Community Action Program, Office of Economic Op. portunity, to the National Conference on Law and Poverty, June 25, r965 [hereinafter cited as Berry Address], reprinted in Law and Poverty 127-28. See Cohen, Law, Lawyers and Poverty, 43 Texas L. REv. $27 \mathrm{r}$ (1965).

${ }^{78}$ Berry Address, reprinted in Law AND Poventy 124. 
Another factor was added by the new requirement that "lawyers from minority groups must also participate in formulating the legal service program and be represented on its governing board."79 Again it was emphasized that while it was not an "absolute requirement" that legal service proposals be approved by community action agencies, it was "desirable that the community action agency be used" unless it "can be shown that it is not possible, after reasonable effort has been made to coordinate activities with the agency." 80 At the same time Mr. Berry stressed that the program must be "independent in its control and operation so that it will remain free to litigate cases" involving its parent organization or organizations represented on its board of directors. ${ }^{81}$ It was again suggested that a legal program should provide a full range of services to individuals, ${ }^{82}$ provide representation for organizations, ${ }^{83}$ and engage in community education. ${ }^{84}$ Unlike the Guidelines, no emphasis was placed on the role of legal service programs in law reform, except to encourage law schools to engage in research into areas of law affecting the poor ${ }^{85}$ Specific mention was made of the need for a lawyer referral mechanism which "should be fair to all members of the bar including neighborhood lawyers and those in minority groups." ${ }^{\circ 6}$

During the summer Theodore Voorhees, NLDA President, Howard C. Westwood, NLDA Washington representative, and Junius L. Allison, NLDA Executive Director, labored to inform legal aid organizations of the opportunity for federal funding and the changes necessary to obtain OEO approval while working simultaneously to persuade OEO that drastic changes in structure, orientation, personnel, and locations of legal aid organizations could not be accomplished overnight. Flexibility was sought and in August there was good reason to think it had been achieved when Sargent Shriver assured the American Bar Association that "we do not intend to bypass the organized Bar or to exclude legal aid and public defender agencies from our deliberations or financial assistance." ${ }^{87}$ Mr. Shriver went on to attempt to allay fears that the original guidelines would be applied literally:

Our statute requires maximum feasible participation of the poor in all aspects of anti-poverty programs. We intend to carry out the mandate of Congress on this. But to do so does not require the imposition of inflexible and arbitrary quotas. We have already financed legal service programs approaching this requirement in a variety of ways. We believe in flexibility. But flexibility cannot become a euphemism for evasion of our statutory duty. ${ }^{88}$

"0 Id. at 123 .

${ }^{80} \mathrm{Id}$. at riz.

${ }^{81}$ Id. at 123 .

${ }^{82}$ Id. at 125 .

${ }^{83} \mathrm{Id}$. at 126 .

${ }^{84}$ Ibid.

${ }^{85}$ Id. at 127 .

${ }^{86} I d$. at 125 .

${ }^{87}$ Shriver, The OEO and Legal Services, 51 A.B.A.J. 1064, 1065 (1965).

${ }^{88}$ Address of Sargent Shriver, before the Assembly, American Bar Association, Miami, Fla, Aug. II, 
In the same address he announced the establishment of a National Advisory Committee on Law and Poverty. Included in its membership were the President, immediate past President, and President-elect of the American Bar Association, the Chairman of the ABA's Standing Committee on Legal Aid and Indigent Defendants, the Chairman of the ABA Special Committee on Availability of Legal Services, the President of the National Legal Aid and Defender Association, and the President of the National Bar Association.

In September of 1965 , E. Clinton Bamberger, a Baltimore attorney with a background of distinguished service in bar association work, was named Director of a newly created Office of Legal Services within OEO. Although the funds for legal service programs were to be obtained from the CAP budget, a greater degree of independence was provided with assurances of a direct channel of communication to the Director of OEO, when needed. The Office of Legal Services was promised $\$ 15,000,000$ to $\$ 20,000,000$ with which to fund local programs during the present fiscal year. Mr. Bamberger chose as his Deputy Director, Earl Johnson, Jr., who brought with him experience gained from ten months of outstanding service in the Washington Neighborhood Legal Services Project.

In November a new policy memorandum, An Introduction to the Development of Legal Services Programs, was prepared. The function of the national program was described as five-fold: to assist community efforts to provide legal advice and representation for people too poor to employ counsel, to encourage and support experimentation and innovation to determine the best methods of providing legal services to the poor, to sponsor education, research and publications in areas of the law that affect the problems of poverty, to acquaint the practicing bar with their essential role to combat poverty, and to provide the means for the involvement of lawyers in the "war on poverty," and to educate the poor to know and recognize the aid of the law. ${ }^{89}$ No mention was made of law reform or community involvement in the goals sought to be achieved.

The ordinary role of a legal services program as a component part of a community action program was noted, but it was now made clear that "if there is no community action agency or if the existing community action agency does not wish to consider a legal services component, ${ }^{\text {,go }}$ direct application could be made to the Office of Economic Opportunity. The necessity for the maximum feasible participa-

1965. The abridgment of Mr. Shriver's speech in the American Bar Association Journal does not contain this language. It does contain this paragraph: “. . . Eighth, we are not trying to dictate to local legal aid organizations and to the public defender agencies the precise composition of the boards of directors of those agencies. Our basic statute passed by Congress requires maximum feasible participation of the poor in all aspects of the antipoverty programs. We intend to carry out that mandate of Congress, but to do so does not require imposition of inflexible and arbitrary quotas." Shriver, supra note 87 , at 1065 .

${ }^{80}$ An Introduction to the Development of Legaz. Services Programs (preliminary draft, Nov. 1965) 2 [hercinafter cited as NovEMBBer Gumenines].

${ }^{\circ}$ Id. at 4. (Emphasis added.) 
tion of the poor was stressed but it was also indicated that "there is no national standard for compliance with the provision that the poor must be represented."

The necessity of independence from the local community action program was emphasized. In the spring, the Guidelines had stated cautiously that "consideration should be given" to the problem of the insulation of legal services from the local community action program with the admonition that "it will require careful planning to assure independent administrative control of the program." stressed that the legal services program "must be independent in its control and operation." "03 In November, it was stated that avoidance of the danger of conflict of interest "requires a clear separation between the community action agency and the legal services program."

The new memorandum, like its predecessor, made it clear that "there should be no limit to the scope or type of legal services provided to eligible clients" and that "all areas of the law traditionally dealt with by attorneys should be included and a full spectrum of legal work should be provided." ${ }^{\circ 5}$ It was suggested that where there was a question of whether the fee generated by the case was sufficient to retain a private attorney, a procedure might be established whereby two or three private attorneys would be given the "right of first refusal" before counsel was provided by the local program. In the spring the Guidelines had stressed the desirability of providing representation for "organizations of the poor such as credit unions, cooperatives, and block clubs" both in organizing and litigating. ${ }^{.6}$ No mention was made of this function in the November memorandum..$^{97}$

The November memorandum, like the spring Guidelines, recognized the importance of an educational program to apprise the poor of their rights and obligagations. The methodology suggested was different. In the spring it had been stated in these terms:

Consideration should be given to the form the legal education will take. For example this education may include personal contact with small groups, such as churches and block clubs, by lawyers, whether working for the program or as volunteers, by consumer education experts, and by others to discuss legal rights and the legal service program, distribution of model legal forms to help residents with installment contracts, leases, etc., and attempts to persuade businessmen to use them; dissemination of legal information by social workers and other workers in the neighborhood as part of their regular work and notification by public agencies to the people with whom they deal that legal counsel is available to represent them before the agencies. ${ }^{98}$

\footnotetext{
${ }^{\circ 1}$ Id. at 5 .

22 SPRING GUIDELINES $\mathrm{II}_{4}$.

92 Berry Address, in LAw AND Poverty 123.

Q4 November Guidelines 6.

${ }^{95}$ Id. at ro.

${ }^{98}$ Spring Guidelines 196.

'7 November GuIdeLINES IO.

${ }^{88}$ SPRING Guidelines 118 -19. (Emphasis added.)
} 
In November the approach was somewhat different:

... Law schools, the organized bar and individual attorneys should be involved in this phase of the program. A strong "preventive" law approach should be established, educating potential clients to become aware of their legal rights and protect them so that legal remedy to be sought after involvement will be the exception rather than the rule. The application should state the method of preventive law. For example this education may include discussions with church groups, block clubs and other groups of poor people to inform them of their legal rights and the availability of the legal services program; a bar association may prepare and distribute model forms of installment contracts and leases; and public agencies should be encouraged to inform poor people that legal counsel is available. ${ }^{99}$

There can be little doubt that the November formulation looked towards education of the poor by lawyers. The social worker and the subprofessional should be assigned to different tasks.

The November memorandum made it clear, however, that programs would be evaluated on the basis of answers to two questions: (I) What was the quantity and quality of legal work for clients, and (2) what contributions did the program make to eliminate the cause and effects of poverty. ${ }^{100}$

In January a new Guidelines for Legal Services Programs was drafted with the admonition that it, like its predecessors, was a preliminary copy and that a booklet containing definitive guidelines would be published shortly. Few changes had been made since the November memorandum.

Again it was asserted that ordinarily a legal services program would be a component of a local community action program, but exceptions were outlined where the applicant was able to provide "reasonable evidence to justify direct funding" and "evidence that it has made every reasonable effort to coordinate its activities with those of the broadly-based agency." "101 The June speech was echoed in the requirement that the board include representatives of minority groups. ${ }^{102}$ In this memorandum it was suggested that in order to achieve coordination with social services, the legal services program might work closely "with a trained person on the staff of a community action agency or social work delegate agency or that the staff may include a person trained in the field of social work." 103 No mention was made of law reform or group representation. While it was again made clear that one of the criteria for evaluating the program would be the contribution that it has made to eliminate the causes and effects of poverty, ${ }^{104}$ it was not suggested how any long range effect could be accompanied without substantial involvement in law reform or group organization and representation.

\footnotetext{
${ }^{\circ 0}$ NoveMber Guidelines at II-I2. (Emphasis added.)

${ }^{100} \mathrm{Id}$. at 12.

201 JANDARY GUIDELINES 5.

${ }^{103}$ Id. at 9 .

${ }^{108}$ Id. at 20.

${ }^{104}$ Id. at I7.
} 
It would be unfair to conclude that $\mathrm{OEO}$ consciously has determined to ignore law reform and lawyer participation in group organization and representation solely on the basis of the failure to mention these functions in the later internal policy memoranda. In at least one case $\mathrm{OEO}$ has required a local organization to promise that groups would be represented as a condition for federal funding. ${ }^{105}$ Undoubtedly there will be language speaking of the importance of law reform in future permanent guidelines. ${ }^{105 a}$

However, there certainly has been no emphasis placed upon achieving institutional change through group organization and representation and efforts aimed at law reform. It seems to have been assumed that these objectives can be achieved by a program in which principal emphasis is placed upon providing lawyers to those in need. The result may be an unintended de-emphasis upon action aimed at the elimination of the causes and effects of poverty.

At the end of 1965 OEO had funded twenty-seven projects in twenty-three local communities and two national projects. A total of $\$ 3,127,217$ had been expended. There were eighteen formal proposals under consideration. Over one hunded other communities had corresponded with OEO in documents ranging from inquiries to informal drafts of proposals. Some of the grants were very small. Other projects had been funded before many OEO policies had been determined. Many of the funded projects were not yet in operation.

Substantial grants had been made to Buffalo, N.Y. $(\$ 106,162)$ to start four neighborhood offices under the Legal Aid Bureau; Clarksdale, Mississippi (\$82,725) to establish one central office with one full-time attorney and five part-time attorneys; Little Rock, Arkansas $(\$ 32,582)$ for the establishment of a full-time Legal Aid Society with a staff of three attorneys; Los Angeles, California $(\$ 333, \mathrm{I} 29)$ for the establishment of Los Angeles Neighborhood Legal Services, Inc., which will operate three neighborhood offices with a staff of ten attorneys; New Bedford,

\footnotetext{
${ }^{200}$ New Bedford, Mass.

105a The Gaidelines for Legal Services Programs, published in February 1966, contain the following provisions:
}

"Free legal services should be available to organizations composed primarily of residents of the areas and members of the groups served. However, the services should not be provided if the organization is able to retain an attorney for the type of representation it seeks. By pooling their resources, a group of individuals may be able to afford counsel in cases where an individual could not. At the same time, the combined resources of the members of an organization may be insufficient to retain an attorney to handle the particular legal problem in which the organization requires representation. A flexible standard should be applied. The factors to be considered include the size of the organization, the relative poverty of the members of the organization, and the cost of the legal assistance which the organization desires."

I966 GUIDELINES at $2 \mathrm{~T}$.

"Advocacy of appropriate reforms in statutes, regulations, and administrative practices is a part of the traditional role of the lawyer and should be among the services afforded by the program. This may include judicial challenge to particular practices and regulations, research into conflicting or discriminating applications of laws or administrative rules, and proposals for administrative and legislative changes."

I966 GuIDELiNes at 23. 
Massachusetts $(\$ 46,409)$ for the establishment of four offices to be operated by a committee of the local community action program using the part-time services of six lawyers; Newark, New Jersey $(\$ 279,269)$ for the Newark Legal Services Project, a new organization, to operate six neighborhood offices and one central office with thirteen attorneys; Oakland, California $(\$ 74,593)$ for the establishment of two neighborhood offices with four lawyers to be run by the Alameda County Legal Aid Society; Omaha, Nebraska $(\$ 69,106)$ to Legal Aid Society of Omaha for the operation of four offices with four attorneys; Pittsburgh, Pennsylvania $(\$ 222,516)$ for the staffing of eight neighborhood offices with eight lawyers under the Legal Aid Society; Portland, Oregon $\left(\$ 11,85^{2}\right)$ to add one attorney to the Legal Aid staff; St. Louis, Missouri $(\$ 267,185)$ for the establishment of Civil Legal Aid Services, a new organization which plans to staff twelve offices with six full-time attorneys; and Washington, D.C. (\$136,874 in $1965 ; \$ 537,706$ for eight months of 1966 ) for the Neighborhood Legal Services Project, a new organization, established by the local community action program. In addition a major research, demonstration and training grant $(\$ 242,579)$ was made to the University of Detroit for a program by which it undertook to reorient its law school curriculum to emphasize urban problems, undertake research into the legal problems of the poor, operate a clinic, and engage in a program of education of the poor concerning their legal rights. Additional grants were made to two Indian Tribal Councils, to the National Legal Aid and Defender Association and the American Bar Foundation. ${ }^{106}$

\section{The First Year at the Local Level: Neighborhood Legal Services Project (NLSP)}

The Washington, D.C., program was the largest OEO-financed project in operation in 1965 . An analysis of its performance may provide insights into directions in which OEO programs may go at the local level.

Before the beginning of the national "war on poverty," the Ford Foundation had undertaken to make funds available to several cities to finance programs designed to restore vitality to the blighted "grey areas." Washington was one of the cities selected and the United Planning Organization (UPO), a non-profit corporation, was created to receive the funds and coordinate local efforts. Prior to the organization of UPO, a pilot study of poverty in the Cardozo area of central Washington had been initiated by the Washington Action for Youth (WAY), and a substantial grant had been received from the President's Committee on Juvenile De-

\footnotetext{
100 The prestigious American Bar Foundation has undertaken a study of many of the most important questions underlying the problem of providing legal services to the poor. Under the direction of Professor Geoffrey C. Hazard, grants by the Foundation to Professors Robert S. Schoshinski, Bernie R. Burrus, and John R. Schmertz, Jr., of the faculty of Georgetown University Law Center, have permitted research by these gentlemen which has been of great assistance to the author in formulating the views expressed in this article.
} 
linquency for funding projects in that neighborhood. UPO ultimately assumed the programs and grants of WAY.

In 1964 Washington had a private Legal Aid Society which had been in operation for thirty-two years. On a budget of approximately $\$ 100,000$, provided by the Bar and the United Giving Fund, it was providing representation for the poor in civil cases at one office located in downtown Washington, a branch office at Howard University, and an office in the District of Columbia Court of General Sessions. In I960, Congress had created the Legal Aid Agency for the District of Columbia which provided representation to a substantial number of defendants in criminal cases and representation in mental health proceedings. During the early months of 1964 , James G. Banks, the Executive Director of UPO, and William J. Grinker, his assistant, held conversations with a number of Washington lawyers concerning the desirability of establishing neighborhood law offices as a component of UPO's general program. In the specific formulation of the proposal, they were assisted in great measure by Gary G. Bellow, then Deputy Director of the Legal Aid Agency.

The idea of neighborhood law offices was not new. Such offices had been operating in Philadelphia since the late thirties. ${ }^{107}$ However, the Philadelphia offices were primarily aimed only at providing services to individuals who could pay a small fee to an attorney. Different types of neighborhood programs were in operation in New Haven and New York.

Several years previously, William Pincus of the Ford Foundation had reached the conclusion that new approaches were necessary to improve the quality and availability of legal services to the poor. After consultation with local leaders, New Haven, Connecticut, was selected as a city in which an experimental program would be launched.

In Ig62 Community Progress, Inc. (CPI), a non-profit corporation, was created in New Haven. CPI, with grants from the Ford Foundation, the federal government, and other sources, set out to provide a "broad roster" of "effectively coordinated" community services as a method of staging a comprehensive attack on the social problems of some neighborhoods in that city. ${ }^{108}$ Initially each neighborhood staff was to consist of a neighborhood worker and representatives of public and private health, welfare and recreation agencies under a social worker who had the responsibility for coordinating activities. ${ }^{109}$ A neighborhood lawyer was placed on the staff of each of these teams. During the first year of operation the neighborhood lawyers encountered substantial problems. In 1964 the New Haven Legal Assis-

${ }^{107}$ Abrahams, Twenty-Five Years of Service: Philadelphia Neighborhood Lawv Office Plan, 50 A.B.A.J. $728(1964)$.

${ }^{103}$ Address by Charles J. Parker, President, New Haven Legal Assistance Association, before the National Conference on Law and Poverty, Washington, D.C., June 25, r965 [hereinafter cited as Parker Address]. See also Parker, The New Haven Model, in HEW Conference Proceedings 8793; Cahn \& Cahn, The War on Poverty: A Civilian Perspective, 73 YALE L.J. 13I7 (1964); InW AND POVERTY 76.

${ }^{109}$ Parker Address at 5. 
tance Association, Inc. was organized to operate the legal services program. ${ }^{110}$ Independent neighborhood law offices were established. During the months in which UPO was preparing its proposal, Legal Assistance Association, Inc. was being investigated by a special committee of the local bar association which ultimately resulted in local bar association opposition to the program. ${ }^{111}$

In Ig64 Mobilization for Youth opened a neighborhood office in New York City's lower East Side. ${ }^{112}$ It attempted to integrate its operations with those of neighborhood social workers. No attempt was made to handle all cases coming to it. Routine cases were referred to the New York Legal Aid Society or others. Cases were retained which involved a principle with "pervasive impact" upon a substantial segment of the community or where other representation was not available. ${ }^{113}$ It concentrated on direct education of the poor, undertook a number of test cases, and participated in the organization of tenant and consumer groups. ${ }^{114}$ To a large extent it provided the model for the UPO proposal.

In May Ig64 a proposal by UPO to the Defender Project of the National Legal Aid and Defender Association sought funds for improvement of the Legal Aid Agency and local law school programs in criminal law. This proposal referred to the possibility of the establishment of neighborhood law offices. During the summer Chief Judge David L. Bazelon of the United States Court of Appeals for the District of Columbia Circuit appointed a special committee under the chairmanship of Circuit Judge J. Skelly Wright to study the desirability of neighborhood law offices. After several meetings and discussions of drafts, the Committee approved a September I964 proposal submitted by the United Planning Organization. This proposal constituted the basis for the organization of the Neighborhood Legal Services Project (NLSP).

The proposal accepted the conclusions of the $195^{8}$ Commission on Legal Aid of the District of Columbia Bar Association that the legal aid organizations in the District of Columbia fell short of meeting the need; that the services were inaccessible to many; that others were unaware of the existence of the services; and that the contributions of the present programs were limited by the partial isolation of legal assistance from other agencies in the community. ${ }^{115}$ A clear need was seen for a program which would re-examine the legal rules and procedures affecting the poor, as well as to provide services. The main elements of the proposal included the establishment of neighborhood law offices "in coordination" with the Legal Aid

\footnotetext{
${ }^{110}$ Id. at 3 .

${ }^{111} I d$. at 7,8 .

${ }^{112}$ LAw AND Poverty 69-74; Grosser, The Need for a Neighborhood Legal Service and the New York Experience, in HEW Conference Procendings at 73-80. See also Sparer, The Role of the Welfare Client's Lawyer, 12 U.C.L.A.L. REv. 336 (1965).

${ }^{113}$ LaW and Poverty 70.

214 Id. at 70-71.

116 United Planning Organization, Proposal for Neighborhood Legal Services for the IndiGENT I-3 (r964) [hereinafter cited as UPO Proposaz].
} 
Society of the District of Columbia; development of an effective system of screening and referral of non-indigent cases; coordination of legal services with agencies providing non-legal services to lower economic groups; development of educational and clinical training programs for lawyers, law students and graduate students in other disciplines concerned with the problems of the poor; and the initiation of nontechnical educational programs on legal rights, obligations and remedies for the residents of the community. ${ }^{116}$

Heavy emphasis was placed on the role of research directed at the long-range impact of the program and to short-range research projects directed at the reevaluation of standards of indigency, the mechanism of lawyer referral, and similar matters. ${ }^{117}$

The new offices were to function in "close coordination with the offices of the Legal Aid Society" but independently. ${ }^{118}$ There was to be consultation on standards of eligibility and maintenance of records, and cooperation in the utilization of nonlegal services. If feasible, one full-time or part-time Legal Aid Society attorney should be in each neighborhood office. ${ }^{119}$ The basic nature of the neighborhood offices was made clear:

It is recognized that the neighborhood law offices will not be able to handle a large proportion of the cases coming from the community. Allocation between the Legal Aid Society offices and the neighborhood law offices will be made on a case-by-case basis in accordance with standards developed after discussion with the Legal Aid Society based on experience in the neighborhood. The Legal Service Program is conceived as supplementing rather than competing with existing legal aid organizations. Attempts will therefore be made to concentrate on types of cases which place burdens of time and resources on existing legal aid organizations beyond their present capacities. Consideration will also be given to accepting cases involving individuals who have had contact with the staff of the Neighborhood Development Program. Such cases will afford a basis for further experience in the effective coordination of legal and nonlegal services. ${ }^{120}$

The program was "conceived as an adjunct to existing legal aid, entering areas and exploring methods not heretofore fully explored by legal aid organizations."121

Provision was also made for close cooperation with the Legal Aid Agency in criminal matters. Clear emphasis was placed on the coordination of legal services with agencies providing non-legal services. ${ }^{122}$ It was anticipated that there would be consultation on individual cases between staff attorneys and social workers supplemented by an informal continuing relation for the purpose of clarifying the

\footnotetext{
${ }^{110}$ UPO Proposal $4 \cdot 5$.

${ }^{217} I d$. at $14-15$.

${ }^{118}$ Id. at 5-7.

${ }^{220} I d$. at 6.

${ }^{120} \mathrm{Ibid}$.

${ }^{121} I d$. at 19.

${ }^{122}$ Id. at 8-1o.
} 
problems of the client, developing solutions to avoid anticipated future problems, and the exploration of new interviewing and consultative techniques. ${ }^{123}$

The new program was to be a component of the UPO but supervision and control over it was to be vested in an uncompensated board of directors made up of members of the bar and the judiciary. ${ }^{124}$ Specific provision was made that UPO "will exert no control over the operation of the project after initial consideration of the proposal and the budget."125 Neighborhood offices were to be established in areas included in UPO's Neighborhood Development Program. ${ }^{126}$ Each office would have full time lawyers, an investigative staff, and clerical personnel. ${ }^{127}$ Volunteer attorneys and interns pursuing graduate programs in legal problems of the poor would supplement the staff. ${ }^{128}$

In November of 1964 NLSP was created by action of the UPO Board of Trustees. It has no separate legal existence. The President of the Board of UPO chose eleven private practitioners, one government attorney, the Deputy Director of the Legal Aid Agency, and two law school professors to serve on the board. The author was selected as chairman.

The board met for the first time on December 7, 1964. Included in the membership of the board was the President of the Washington Bar Association, a former President of the D.C. Bar Association, three members of the Board of Directors of the D.C. Bar Association, the current Vice-President and immediate past VicePresident of the Legal Aid Society Board of Directors, two members of the Legal Aid Agency's Board of Trustees and the Deputy Director of the Agency, two members of the Ethics Committee of the D.C. Bar Association, and a member of the District Court's Committee on Admissions and Grievances. ${ }^{129}$ During the year there were to be four resignations; one member was appointed to the federal bench, a second to the position of United States Attorney for the District of Columbia, and a third as Deputy Executive Director of the United Planning Organization.

The immediate problems involved staffing, determination of job descriptions and salary scales, the formulation of basic policies, and the establishment of neighborhood offices. The board met weekly during the first two months. Committees dealing with policy, personnel, relations with the bar, and relations with UPO met regularly between meetings. The top level staff was appointed, the initial policy determinations made, and the first office opened by the beginning of January.

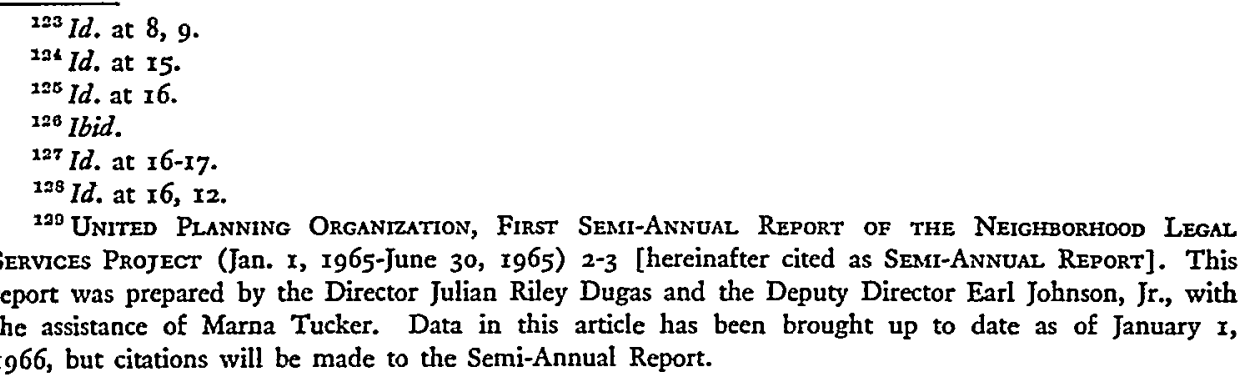


Julian R. Dugas, an attorney in private practice with substantial government experience in the Office of the Corporation Counsel, was selected as Director. Earl Johnson, Jr., an attorney with the Criminal Division of the Department of Justice, accepted an appointment as Deputy Director. The functions of the project were outlined as follows:

r. To advise residents of low-income neighborhoods concerning their legal problems;

2. Where appropriate, to represent them before Courts, administrative agencies and boards;

3. Where otherwise appropriate, to refer them to other agencies providing legal services to the poor, such as the Legal Aid Society and Legal Aid Agency;

4. To enhance the ability of residents of low-income neighborhoods to foresee common legal pitfalls and avoid them;

5. To identify non-legal problems in our clients' situations and guide them to resources within the United Planning Organization or in the rest of the community which can minister to their needs;

6. To promote legal education and research concerning the law most relevant to the problems of the poor. ${ }^{130}$

It was determined that no member of the staff would be permitted to engage in the private practice of law. Initially no registration fee would be charged until a study of the effect of the traditional practice of minimal registration fees upon relationships with clients could be conducted. ${ }^{131}$ The eligibility standards followed by the Legal Aid Society since rg6r were adopted, pending future study. ${ }^{132}$ The Lawyer Referral Service of the D.C. Bar Association was selected as the device for referral of ineligible applicants, until a system of referrals to neighborhood lawyers could be developed. ${ }^{133}$

It was agreed that NLSP would accept for direct handling cases involving legal problems in the fields of housing, consumer credit, public assistance and veterans' benefits; juvenile problems; adult felony cases before the initial appearance in court; and adult misdemeanor cases where counsel could not be provided by the Legal Aid Agency. ${ }^{134}$ Domestic relations cases would be referred automatically to the Legal Aid Society, but in custody or non-support actions where both parties were indigent, and the Legal Aid Society was representing one party, NLSP would

${ }^{130}$ Semi-AnNual Report at $\mathrm{I}$.

131 Id. at 4 .

${ }^{132} I d$. at 5: The standard is: "A base minimum income which would not permit the payment of legal fees would be for a single person $\$ 55.00$ per week take-home pay, for a married couple $\$ 70.00$ per week take-home pay, and for families with dependent children and aged family member $\$ 70.00$ per week take-home pay, plus $\$ 15.00$ per week for each such dependent."

Account must be taken of special circumstances, including outstanding debts, illness, recent unemployment and the probable extent of equity in any property which is owed. "In addition representation is not provided to an applicant who has a claim which a private attorney would be willing to handle on a contingent fee basis."

${ }^{133} I d$. at 5,6 .

${ }^{134}$ Id. at 6 . 
undertake to represent the other. ${ }^{135}$ Permission was granted to undertake other types of cases, but priority was to be accorded to the designated categories. ${ }^{136}$ The board attempted to prevent the overburdening of the staff by granting discretion to staff attorneys to decline representation of eligible applicants and to refer such cases to the Legal Aid Society. It provided that before deciding whether a given case should be accepted or referred, the staff attorney should consider the extent to which the legal problem was related to the non-legal program of UPO, the extent to which the legal program was not being handled adequately by other agencies because of a shortage of staff or financial resources, and the extent to which the problem involved legal issues of general significance to the poor of the area being served..$^{\mathbf{1 3 7}}$

It was recognized that groups might seek representation and that no specific rules could be formulated which would be adequate to cover groups of different composition, resources and objectives. The board agreed that requests for representation by groups should be referred to the Director who would then submit a recommendation to the Executive Committee of the board. In determining whether to undertake representation of a particular group, consideration would be given to the size of the group, the relative poverty of its individual members, the probable expense of representation in addition to attorney's fees, the time and effort required to provide adequate representation, and the recovery anticipated, if any ${ }^{138}$ Authority was also granted for staff attorneys to provide advice to other components of UPO in emergency situations, with the understanding that the UPO component and not its clients would be the NLSP client. ${ }^{139}$ The staff was specifically instructed to formulate a broad program designed to educate the neighborhoods being served concerning basic legal rights and obligations and the availability of legal services. ${ }^{140}$

The first neighborhood law office was opened on January 7,1965 , in the Cardozo area. Application was made to OEO for funds to open additional offices outside of the Cardozo area shortly after its opening. During February I965, two offices were opened in the southeast section of the city. In April, a second office was opened in the Cardozo area. The last of the three Cardozo area offices was placed in operation and a sixth office opened in central Washington during June. By the end of 1965 two additional offices were in operation in northeast Washington. Two new offices were planned for I966. Several of the offices were located in storefronts, several in the same building as other UPO components, others in the only rentable space which could be obtained.

At the end of $196_{5}$ the staff consisted of a secretariat composed of the Director, Deputy Director, Administrative Assistant (non-lawyer), Staff Assistant (lawyer),

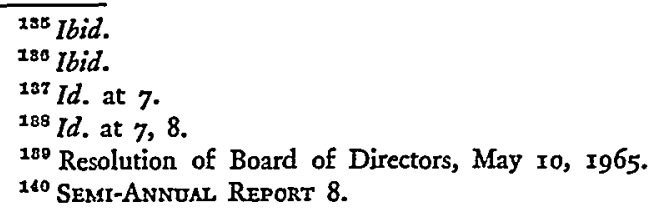


and an Executive Secretary; and eight offices manned by twenty-one staff attorneys, eight legal secretaries, four clerk-typists, and twelve investigators. It had an operating budget of approximately $\$ 700,000 .^{141}$ Funds for 1966, with the exception of the local contributions, were made available by OEO. By the end of I 966 a staff of ninetythree, including thirty-five lawyers, was planned. ${ }^{142}$

The staff attorneys have diverse backgrounds. The age range is between twentyfour and sixty, the average age is thirty-nine. The staff includes graduates of the law schools of American University, Boston College, Catholic University, University of Chicago, Cornell University, Georgetown University, George Washington University, Harvard University, Howard University, University of Iowa, University of Virginia, and Yale University. Nine staff members were on law reviews; nine were in the upper quarter of their law school graduating class; five ranked in the top ten per cent. The level of legal experience of staff members ranges from less than one to over seventeen years; the average is five. Approximately one-half had prior experience in private practice. Ten had government experience in the Departments of Justice or Labor and the Office of the Corporation Counsel. Two had previously served with the Peace Corps. ${ }^{143}$

Few staff attorneys had expertise in the legal problems of the poor when they joined NLSP. An emergency training program was initiated immediately with the assistance of professors from local law schools, volunteers from the bar, and staff members of other UPO components. ${ }^{144}$ A legal secretary with considerable experience in the operation of legal aid was retained to develop a directory of the social resources available in the community to which non-legal problems could be referred. ${ }^{145}$ She also provided valuable assistance in the beginning of an NLSP manual which includes forms, guidelines, procedures and other materials to assist a lawyer joining the staff. A formal training program was conducted at Howard University as a result of an OEO training grant. This program was designed to provide more detailed instruction in the special problems involved in the representation of the poor. ${ }^{14 \mathrm{e}}$ Considerable materials were accumulated but the intensive systemized training program sought by the board failed to develop, in large measure because of administrative difficulties encountered in dealing with Howard University.

An effort was made to develop a community education program. Speeches were made to over one hundred groups by staff attorneys. ${ }^{147}$ A pamphlet was prepared outlining rights and obligations in consumer credit and landlord-tenant relationships and the availability of Legal Aid Society and NLSP to provide advice to those

${ }^{212}$ On December 30,1965 , OEO approved a budget of $\$ 537,360$ for eight months of the fiscal year. GR. NO. DC CAP 66-380.

${ }_{143}$ Ibid.

${ }^{113}$ Semi-AnNual Report I5, I6.

14. $1 d$. at 16.

${ }^{145}$ Id. at 36-39. Invaluable assistance was provided by Miss Blossom Athey.

${ }^{140} 1 d$. at 16.

${ }^{147}$ ld. at 35. 
in need of assistance. ${ }^{148}$ A manual was also developed for non-professional neighborhood workers to enable them to recognize when a member of the community needed legal assistance. ${ }^{140}$ At the close of the year a referral manual was prepared for UPO and other social agencies in order to facilitate the referral of cases involving legal problems to NLSP and Legal Aid Society. ${ }^{150}$ At the end of the year NLSP was considering other programs seeking to utilize radio and television for educational purposes.

Staff attorneys and law students undertook research memoranda in several areas and cooperated with local law schools in providing problems for faculty and student research. Test cases involving a retaliatory eviction and the right to bail in the juvenile court were litigated. One became moot and the other was pending at the end of the year. The Director provided advice to an individual congressman concerning proposed legislation amending the housing code and responded to a questionnaire from the District of Columbia Crime Commission. The board undertook to study and to endorse in principle housing legislation proposed by another organization. No formal proposals for changes in existing law were initated by NLSP.

There were frequent consultations between the top level staff and officials of UPO, attorneys in the neighborhoods attended neighborhood center meetings with counterparts from other UPO components, and a high level of mutual referrals developed, resulting in almost fifty per cent of NLSP applicants receiving advice both from a lawyer and from some other component of UPO. ${ }^{151}$ Joint consultations were the exception rather than the normal routine. NLSP staff complained of a lack of understanding by UPO staff of the role of the lawyer, and UPO neighborhood center heads complained that staff attorneys were not serving as members of the UPO team.

During the first year no groups were represented either in organizing or in litigating, although staff attorneys did provide advice to individuals seeking to organize on several occasions.

During the year 4,937 persons applied for services at neighborhood offices. ${ }^{152}$ There was an average caseload of fifty cases per attorney with approximately forty new cases each month in the five offices which had been open six months or more. Slightly less than one half of the applicants came directly to the offices; almost one half were referred by a component of UPO or by some other social agency. NLSP attorneys retained approximately two-thirds of the cases for direct handling. Approximately nine per cent were referred to the Legal Aid Society. Over three per cent were sent to lawyer referral, approximately seventeen per cent were referred to other

\footnotetext{
${ }^{148}$ Id. at 36.

140 $1 d$. at 37; Neighborhood Legal Services Project, When People Need a Lawyer (ig65).

${ }^{200} \mathrm{Id}$. at 37 .

${ }^{101}$ Id. at 34 .

${ }^{102}$ NLSP Monthly Progress Report, Jan. 1966.
} 
UPO components for non-legal services, and slightly over seven per cent were sent to other social agencies. Ten per cent were rejected without referral. ${ }^{153}$

Over thirty per cent of the cases involved housing problems. Consumer rights problems accounted for approximately eleven per cent. Eight per cent involved welfare problems. Slightly over seven per cent involved adult criminal matters, while juvenile problems constituted over five per cent of the total. The remaining cases covered a wide spectrum. ${ }^{154}$

Results were generally good. In a high percentage of cases evictions were prevented or postponed, criminal charges dismissed, or favorable settlements negotiated. ${ }^{155}$ Flagrant miscarriages of justice were avoided in a number of cases..$^{156}$

Despite the large number of cases undertaken by NLSP, no reduction in the caseload of Legal Aid Society (LAS) resulted. In fact LAS reported the largest caseload in its history for $1965 .{ }^{157}$ There could be no doubt that the services existing before 1965 did not meet the real needs of the city.

At the close of 1965 many observers questioned whether the bar would continue to provide the funds necessary for LAS in view of the federal appropriations available to NLSP. Furthermore, the existence of two organizations with concurrent jurisdiction over civil legal aid and with referrals from one to the other seemed unnecessarily complex and contrary to the best interests of the poor of the city. The decision of NLSP to refer domestic relations cases to LAS and the refusal of LAS to undertake the representation of clients seeking a divorce unless it was "socially desirable" created a gap in services that could not be tolerated on a permanent basis. In December of 1965 the Judicial Conference Committee on Civil Legal Aid requested the views of LAS, NLSP, and the Bar Association of the District of Columbia concerning the desirability of merger.

The difference in structure of the two organizations posed formidable problems. During 1965 the Board of Directors of NLSP twice declined to accept proposals that representatives of the poor sit upon the board. The board thought it essential that an opportunity be provided the residents of the neighborhoods being served to be heard, to criticize and to propose changes. However, it thought that this could be accomplished in a more meaningful way by the formation of neighborhood advisory committees which would be invited to appear before the board at regular intervals. The board questioned the expertise of the representatives of the poor to select the

\footnotetext{
${ }^{163}$ SEMI-ANNUAL REPORT 29. Included in this category were applicants who financially were ineligible for NLSP services, but who selected an attorney without NLSP referral.

184 Id. at 27,28 .

$1057 d$. at $29-33$.

${ }^{100}$ See notes 35,36 supra. In other cases, NLSP obtained favorable settlements for a client who had paid $\$ 395$ plus $\$ 108$ in carrying charges for a television set with a suggested retail price of \$rg9; obtained the release of a six-year-old child who had been detained by juvenile authorities for over five months without authority; obtained the return of a down payment after a merchant refused to deliver merchandise purchased on credit and insisted that the down payment be applied towards the purchase of other merchandise.

${ }^{157}$ See Schein, Legal Aid Utopia, 33 D.C.B.J. 16, 20 (I966); Bamberger Baltimore Address.
} 
best qualified attorneys for the staff, fix salary scales, negotiate a system of lawyer referral, coordinate activities with the Legal Aid Society, maintain good relations with the bar, work out the relationship with the United Planning Organization, oversee the conduct of litigation seeking to restrain it from providing services, determine the appropriate books for office libraries, and dispose of similar matters with which the board was concerned. In the long run other members were troubled by the necessity of filling future vacancies on the board with board members selected in part for their fund-raising potential if additional local funds were to be raised to expand the program. There was genuine fear that the board might grow too large to be effective.

Pressure from UPO and OEO developed, as criticism of the poverty program for its failure to "involve the poor" was voiced in the Congress and the press. Under pressure the board agreed that three of its fifteen members would be selected by the poor in the neighborhoods being served. OEO served notice that the number must be increased to five at the end of I966. LAS continued with its board unchanged.

At the end of its first year NLSP could look with pride at its representation of persons who otherwise would have been unable to obtain counsel. The UPO neighborhood advisory councils praised its performance. ${ }^{158}$ Indeed, some measure of its success may be indicated by the fact that three lawyers filed suit against it and the Legal Aid Society seeking treble damages and injunctive relief for a claimed violation of the antitrust laws. ${ }^{159}$ In addition a few attorneys who practice primarily in the landlord and tenant and small claims divisions of the District of Columbia Court of General Sessions voiced complaints over too aggressive representation and too frequent assertion of procedural rights by NLSP attorneys.

The community education program, although still in its infancy, was off the ground and seemed capable of imaginative expansion during the second year. NLSP could take some satisfaction in the fact that its policies had been used as a model for the development of OEO guidelines in many particulars.

However, a price had been paid for the valuable services rendered to the residents of the neighborhoods. NLSP gradually became service-oriented without any decision by its board to proceed in that direction.

During its first year it failed to realize the objectives of an experimental program which would re-examine systematically the legal rules and procedures affecting the poor, which would investigate new areas and utilize new methods in the representation of the poor, which would coordinate effectively legal and social services for a joint approach to the problems of the poor. It did not develop into a program in which attorneys, relieved of heavy caseloads, could concentrate on a limited number of cases of significance to the community, could develop drafts of

\footnotetext{
${ }^{158}$ The Washington Post, Nov. 19, r965, p. B-r.

${ }^{100}$ Harrison v. United Planning Organization, Civil No. 2282-65, D.D.C.
} 
new rules, regulations and statutes, and could provide leadership in the formation and representation of neighborhood organizations.

The reasons for its failures were complex. The board, the staff, and UPO shared the responsibility. The board spent the year dealing with major problems of policy but had little opportunity to evaluate the extent to which its policies were being implemented. Much of its time was devoted to trying to find out what was happening in the neighborhood offices, determining whether there should be poor on the board, explaining its purposes and operations to the bar, establishing a system of neighborhood lawyer referrals, and attempting to work out its anomalous relationship with UPO. In theory it had the responsibility to administer and control the legal services program but UPO approval was needed for its budgets, UPO contracted for its office space, provided its supplies and paid its staff, and distributed its educational material (under the name of UPO). UPO regarded NLSP as part of its team and NLSP staff attorneys as its employees.

The staff attorneys performed their tasks with an attitude of dedication and provided aggressive representation for individual clients. But many demonstrated an approach of cautious conservatism towards the subjects of group representation, participation in attempts to organize groups, and relationships with social workers and UPO organizers. Some of the senior staff members demonstrated a rigid attitude towards indigency standards, an interpretation of the canons of ethics which was, perhaps, unduly strict, and a literal approach to board policies. A selfimposed restraint developed on activities other than individual representation and community education. Some assumed that they should not act unless the board had ordered action, rather than acting with prudence if the board had not denied authority.

The board and the staff shared responsibility for failing to formulate and articulate a clear statement of the lawyer's role in community protest and organization. The situation was complicated by disagreements within the board concerning what kind of a showing a neighborhood group should make with reference to its inability to obtain private counsel and the relative merits of providing an NLSP lawyer or a volunteer attorney to neighborhood groups.

UPO was a small organization when NLSP began operations. It expanded quickly but with the consequence of administrative chaos during the first six months of NLSP's existence. NLSP developed at a faster rate than did many of the other UPO components. Many of these programs were not service-oriented and hence had no services to offer a client who had a non-legal problem. Many of the personnel were neighborhood workers without professional training. UPO neighborhood development center leaders differed concerning the objectives and methodology to be employed by the legal and non-legal programs. Some encountered difficulties in understanding what the lawyers were seeking to accomplish and the restrictions placed on their permissible activity by professional standards. 
The pressure on neighborhood law offices to accept cases was great. The original concept of referring cases to the Legal Aid Society had serious shortcomings. The Legal Aid Society already had more cases than it could handle. It had an overworked and underpaid staff. It simply was incapable of providing quality representation for several thousand new clients. The neighborhood lawyer was placed in the situation where he was not sure that a client would be represented adequately if the case was referred. In such circumstances he frequently decided that justice required that he retain the case for direct handling. Furthermore, the citizens of the areas being served wanted lawyers to help them. The maintenance of community support required that they be given representation and NLSP was the only organization capable of providing it.

Whatever its causes, the results were clear. An atmosphere did not develop in which the neighborhoods could look to staff attorneys for leadership in community affairs. NLSP staff attorneys were outsiders who came into the neighborhoods to represent those needing legal services and who left when the task was done. There was a growing lack of confidence between UPO and NLSP personnel. The concept of a joint interdisciplinary approach to social problems disintegrated into a relationship of mutual referrals in which each discipline dealt separately with the particular problems within its expertise. The staff failed to develop a plan which could utilize the services of volunteer lawyers, with a loss of creativity and resources which could have resulted from a greater involvement of the bar.

By the end of $196_{5}$ NLSP seemed to be heading towards a status of a first-rate legal aid society of the traditional type. In January of Ig66 the board undertook to compare its performance with its objectives, with a realization that clearer priorities must be established if something more than individual representation and community education were to be accomplished. It appreciated that it must decide what part of NLSP's energies should be devoted to providing services to individuals and what part should be allocated for different purposes. It must decide whether it should assign attorneys exclusively concerned with law reform, the litigation of test cases, and community education to its central staff or whether these functions could better be performed by individual staff attorneys in neighborhood offices. It must stop the drifting and steer a new course if the opportunities presented were to be used to the fullest.

\section{The Future}

The experience of NLSP would seem to indicate that the choice of a new organization or an established legal aid society will not determine necessarily the nature of a local program. An established society can alter its functions and goals to devote substantial resources toward community education, law reform, group organization and representation; it may formulate programs with local social organizations in order to encourage a joint interdisciplinary approach to the problems of its 
clients; it can decentralize its operation to provide greater accessibility. At the same time a new organization can undertake so many cases for private litigants that it has no remaining resources to devote to any other purpose. It may be true that some existing legal aid organizations may have replaced creativity and imagination with settled routine. However, there is no reason why new people added to their staffs cannot inject vigor into the operation. Likewise, there is no reason to believe that new organizations will not fall prey to bureaucratization as time passes and youthful optimism is blunted by a realization of the dimensions of the problems.

Whatever the kind of organization, new or old, there must be a recognition that the shortage of funds and the plentitude of cases require that priorities be established and resources allocated to enable them to be met. It is doubtful if any organization can represent all eligible applicants and still devote any substantial portion of its efforts towards changing the institutions associated with poverty. Action must be taken by local organizations and OEO to insure that the efforts of old and new organizations do not sink into the abyss of mass low-quality services. Little has been done in this direction.

Thus far OEO has not attempted to establish priorities. Its guidelines seek a commitment from applicants that they will undertake all kinds of legal services to all of the poor at all stages, and simultaneously undertake group representation, research, law reform, bar involvement, community education, and allied activities. Local programs like NLSP will move inevitably towards meeting the demands of the community for services with the sacrifice of emphasis upon other objectives unless there is firm leadership exerted at the national level.

It should be recognized that the consensus which forms the basis for bar support may be jeopardized if $\mathrm{OEO}$ requires local communities to allocate resources to activities aimed at institutional reform. Many lawyers will give steadfast support to organizations designed primarily to provide services to individual poor persons with middle-class legal problems but are either apathetic or opposed to organizations with substantial commitments to providing representation to groups contemplating civil rights demonstrations, economic boycotts, or rent strikes. Many lawyers who have no objection to providing legal services to persons who cannot pay a reasonable fee will balk at the idea of an organization which plans to devote a substantial part of its energies to the representation of groups some of the members of which can afford legal fees acceptable to lawyers practicing in the community. Yet representation of such groups may be an essential ingredient of effective community organization and action.

The loss of some support must be accepted. Groups whose support is sought are entitled to candor regarding the objectives sought to be achieved. Hostility is certain to result in the future if the support of the bar is achieved under the guise of 
giving a poor man a right to counsel when the real objective is providing the legal leadership for institutional reform.

Furthermore we must determine our objectives in order to evaluate our progress. We cannot know whether we are succeeding unless we know what we are trying to accomplish.

It is too early to predict with certainty what will be the long term result of OEO's legal service programs. Certain directions seem likely, unless firm policies are developed in the near future.

It seems probable that most of the funds available for legal services will be channeled through existing legal aid organizations, which have altered their structure to accept representatives of the poor on their boards, have decentralized their offices, have broadened their scope to provide representation in all civil matters, and have in theory undertaken new functions such as community education, the organization of groups, and law reform.

The decision of choice of organization will be made initially at the local level but leaders of the bar who devote their time to helping the indigent will generally have close ties with the local legal aid organization and will have confidence that with funds it can produce the novelty, creativity and imaginative new ideas sought by Washington. OEO may not agree and if it does not it will decline to fund the proposal. Only on rare occasions will OEO fund a new organization against the opposition of the local bar. In a few cities where the bar has become disenchanted with existing legal aid societies, new organizations may gain bar approval. Likewise new organizations will develop in cities with no history of legal aid and new programs, perhaps involving the subsidization of private practitioners, will develop for rural areas. These new organizations will soon fall under the umbrella of organized legal aid and will seek and gain admittance to its councils. ${ }^{160}$

The NLDA will change its standards as more money permits improved legal aid operations. ${ }^{161}$ With the passage of time there will be little difference in the personnel, attitudes, objectives or accomplishments of the old and the new.

The principal objective will be to provide legal services to individuals who cannot afford them. Community education programs will be expanded. More and better lawyers attracted by higher salary levels will inject new ideas into the process in a few test cases which will effect some changes in the law. Caseloads will be much lower than in the older legal aid operations, but much greater than the caseloads of private practitioners. There will be more full time lawyers, and young

\footnotetext{
${ }^{100}$ The National Legal Aid and Defender Association has manifested a willingness to accept the new organizations as members. The Director of NLSP has been elected to its Board of Directors.

${ }^{101}$ Amended Standards for Defender Services and Standards and Practices for Civil Legal Aid were promulgated in 1965 . It is interesting to note that in the amended standards, it is provided that "to the extent feasible and for the purpose of establishing community participation, representation of the areas covered and people served should be included on the agency's governing body or on a separate community arbitrary group."
} 
lawyers with better academic qualifications will be involved. After the first few years many of the best will leave to undertake more lucrative positions in private practice, governments, or business because salary scales will be competitive only at the beginning and lower middle ranges. Those who remain may not compare favorably with their colleagues who represent the major private and public institutions with whom the poor come in conflict. The separate institutionalized system for legal services may provide effective representation in disputes among the poor but may achieve less success in disputes between the poor and the establishment. ${ }^{102}$

Representation will be provided to small groups where the general level of poverty is clear; but the pressure of caseloads, the fear of unfavorable reaction from the bar, and ethical problems will discourage the representation of mixed groups of neighborhood residents in which many are poor but some are middle class. The lawyers will be located in the neighborhoods, but will not be of them. There will be more mutual referrals between lawyers and social workers but little joint action towards dealing with the underlying problems of the neighorhood being served.

The poor will sit on boards of directors, but the basic policies governing matters such as standards of indigency and permissible professional conduct will be determined by the bar. Lawyers will listen, they may even be influenced, but they will decide themselves. In some areas the marginal poor man may be sacrificed in order to protect the marginal lawyer. The quid pro quo for "poor on the board" may be retreat from the battle for the reform of the institutions which contribute to the perpetuation of poverty. In some communities opposition from the local bar will prevent the initiation of any program, no matter how limited in scope.

There will be no national offensive against existing legal economic institutions, be. cause the funds will have been expended to provide emergency relief to the victims of the present system. A decade hence we will need more funds for more lawyers to provide the same services to more people with the same kinds of problems.

In the future the chief problems will be whether OEO shall fund legal service programs directly or require the legal service program to obtain the funds from the local community action program; to what extent regional offices of OEO will be able to block or modify legal service programs which a local bar wants and which the Office of Legal Services of OEO has approved; what share of the national and CAP budgets will legal service programs receive, and to what extent will the policies of the Office of Legal Services be controlled by the Community Action Program within OEO. In short, the issue will be the extent to which a bar-managed program of legal services can be isolated from community action programs and still obtain federal financing.

These are dire predictions. There is still time to avoid such consequences.

${ }^{102}$ See Address by William Pincus before the National Conference on Social Welfarc, Atlantic City, N.J., May 1965. 
We are still fighting the preliminary skirmishes in the war against poverty. Only a small percentage of our strength has been committed. Thus far we have been largely occupied with the task of tooling the war machine. There have been local actions which have resulted in good reports from the front. But tactical successes cannot substitute for strategic victory. Strategy requires a clear determination of objectives and the assignment of priorities to them if all cannot be accomplished simultaneously. Only when the strategy has been determined can we decide what tactics will be most effective.

Perhaps our objective should be more and better legal aid in its traditional form supplemented by community education. Perhaps we will determine that there is a moral obligation to represent all who need help and that this must take precedence over other considerations. Perhaps we will reach the conclusion that the objectives of group organizations and protest and law reform through the litigation of test cases and legislation are more important in the long run. Even then we may disagree how this can best be accomplished.

There are those who say that there is no way to determine the best test cases in advance; that they simply emerge unexpectedly out of a mass of routine matters. There are those who think that reform can be accomplished more quickly through pressure placed on the system by a large volume of cases in which new rights are asserted or attempts made to implement older rights. Such people think that the representation of all needing assistance without segregating efforts directed at community organization or law reform will have the best chance of changing the institutions of society.

Others fear that the representation of all will mean caseloads that will preclude the concentration of effort upon a few cases which may have the greatest impact upon the system. From the many cases involving the poor, a few each year might be chosen with a concentration of effort that would not be possible if an effort is made to undertake all cases.

Many question whether the litigation process is the best device to achieve the reforms sought. The laws which bear heavily on the poor have developed over a long history. Achieving change by decisions in individual cases is of course the genius of the common law. However, few appellate courts, and even fewer trial courts, have demonstrated the crusading spirit of the early common law judges in discarding traditional precedents because of new social attitudes or changed social conditions. In many cases the provisions of law most onerous to the poor are found in statutes or rules incapable of equitable interpretation. Many trial judges in urban areas, faced with the massive problem of court congestion, and conditioned to the summary disposition of small claims and landlord and tenant matters, will shy away from the use of their courts as the laboratories for social experimentation. The political power of the poor can be brought to bear upon legislatures and mayors in a way which is impossible, or improper, with courts. For these reasons some 
have reached the conclusion that many of the changes sought must be accomplished by new statutes, rules, and regulations. Lawyers specially assigned to these tasks may be essential for the drafting and the lobbying necessary to transform grievances into changes.

We may choose to abandon the concept of the lawyer as a catalyst for community organization. We can play down the contribution that can be made through group protest or minimize the importance of the lawyer in helping groups to organize and choose the alternatives most likely to accomplish their goals. During the last century the corporate lawyers played a significant role in the development of our economic institutions. We must now decide if lawyers for the poor will make contributions of equal significance in changing our social institutions. ${ }^{103}$

Many of the decisions facing us must be made at the national level. The pressures in many local communities will result in demands for services now rather than new institutions in the future. OEO has not hesitated to require local communities to adopt its ideas concerning the range of services to be provided or the structure of organizations which will be funded. It should not hesitate to require assurances concerning the number of attorneys, the percentage of resources, and the methodology to be employed in the representation of groups and in law reform. OEO should examine the feasibility of making grants to local neighborhood councils to enable them to retain their own attorney if a community legal services program

\footnotetext{
${ }^{188}$ It is clear that the Director of Legal Services is aware of the problem. In his Baltimore Address, supra note 42, Mr. Bamberger stated:

"We want lawyers to be not only advocates for individuals trapped by poverty, but to be the articulate spokesmen for the fifth of our population who suffer from being poor-invisible, inarticulate, unrepresented, depressed and despairing-living the contradiction of poverty in an afluent society. . . . Lawyers committed to the finest traditions of the bar can speak for the inarticulate, can challenge the systems that generate the cycle of poverty, can arouse the persons of power and affluence."
}

In an Address to the Pennsylvania Bar Association on January 20, 1966, he stated:

"Our pose is not just to stimulate and implement community efforts to provide a lawyer for a poor person in a particular case. We want lawyers to be advocates for a class of people who are inarticulate and unsophisticated-and who do not have advocates. Lawyers will be a voice of the poor in the community. ..."

In his Address to the National Legal Aid and Defender Association's Annual Meeting in Scottsdale, Arizona, on November 18 , 1965, he stated the issue clearly:

"I ask myself each day-how will lawyers representing poor people defeat the cycle of poverty? This is the purpose of the Office of Economic Opportunity, and unless we can justify our contribution to that purpose, the program I direct is not properly a part of the War on Poverty. . . . Our concern is more broad than a compilation of statistics of the numbers of clients, the kinds of cases and even the results. We must address ourselves to the much more difficult task of assessing the impact on the community, its rules, its regulations, and the concern for its disadvantaged citizens."

In his Address to the National Conference of Bar Presidents on February 19, 1966, he stated:

"It is fallacious to think of lawyers as guardians of tradition-rather we are the guardians and watchdogs of orderly change. It is perhaps the greatest genius of the Anglo-American system that we have always, except when confronted with the terrible agony of the Civil War, been able to change the deepest and most fundamental characteristics of our society peacefully, with a stability of government and laws that is the awe and envy of other nations." 
either encounters a conflict of interest or chooses to devote its energies primarily to the representation of private individuals. It should consider funding law school legal internship programs as the instruments of law reform to supplement local servicesoriented legal programs.

Our alternatives are many, once the strategy is determined. The time is now. The profession and the nation cannot afford to miss the opportunity. If we do not determine our strategy soon we can reasonably anticipate a war of attrition in which a decisive victory is impossible. The legal front of the war against poverty must not be permitted to grind to a halt in the mud of a Passchendaele. 


\section{WERE YOU ONE OF THOSE WHO MISSED...}

TWO'S COMPANY

by JoHn S. Bradway

Professor of Law and

Pioneer in the Legal Aid Movement

This article, which examines the obligation of the legal profession to provide legal services for the indigent without the specter of federal interference, appeared in the second issue of the 1966 volume of the

\section{DUKE LAW JOURNAL}

A law review edited and published quarterly by students of Duke University School of Law and devoted to discussion and examination in depth of current legal topics.

Subseription : $\$ 6.00$

Single Copies : $\$ 2.50$

Address all inquiries to

Managing Editor

Dukg Law JournaL

Duke University School of Law

Durham, North Carolina 27706 